ISSN 2413-0877 Volume 2 (2015) 243

The 3rd International Conference on Biological Science 2013

(The 3rd ICBS-2013)

\title{
DIEL DISTRIBUTION OF DESOLVED OXYGEN AT TRADITIONAL-SQUARE SHRIMP POND IN MANGROVE ECOSYSTEM OF BONDAN SEGARA ANAKAN
}

\author{
Tjut Sugandawaty Djohan ${ }^{1}$, Krisni Suhesthiningsih ${ }^{1}$, and Amsal Pasila \\ ${ }^{2}$ Laboratory of Ecology and Conserrvation, \\ Faculty of Biology Universitas Gadjah Mada, Yogyakarta 55281, \\ e-mail: tdjohan95@yahoo.com
}

\begin{abstract}
In 1997, large area of mangrove forest in Segara Anakan was converted into the intensive shrimp-ponds, which were failed, abandoned, and colonized by mangrove shrubs. Some of these abandoned shrimp-ponds were changed into the traditional shrimp-ponds using tides as a source of energy. We aimed to study the diel distribution of dissolved oxygen (DO) at the traditional-square shrimp pond, $250 \mathrm{~m} \times 80 \mathrm{~m}$, during the dry season of October 2009. This pond had one gate for water inflow and out flow from Bondan River, which was automatically open and closed by tides. The island of this shrimp-pond was colonized by aquatic macrophyte, Fimbristylis polytrichoides, which was die-back during the dry season. We also measured $\mathrm{pH}$, salinity, and temperature both at the shrimp pond and the water inflow. We hypothesized that $\mathrm{DO}$ in the traditional shrimp pond was similar to DO of Bondan River. The sampling was conducted for 3-hour periods in the 24 hours. Water samples were taken from 4 points at the canal, 2 points in the center, island, and 2 points at the water inflow of Bondan River. The results showed that DO distribution in the 24 hours were 3.8-9.2 ppm. The DO concentration of the traditional shrimp-pond was higher than DO of the Bondan River. The DO during the day was higher than the night. The lowest DO concentrations were at early morning between $4.7 \mathrm{ppm}$ in the ponds, $3.56 \mathrm{ppm}$ in the river inflow. The DO of the shrimp pond was influenced by the temperature and pH.
\end{abstract}

Key words: Dissolved Oxygen, traditional shrimp-pond, mangrove

ISSN 2413-0877 (c) 2015 The Authors.

Published by KnowledgeE Publishing Services This is an open access article under the CC BY-NC-ND license (http://creativecommons.org/licenses/by-nc-nd/4.0)

Selection and Peer-review under responsibility of the 3rd ICBS-2013

Doi http://dx.doi.org/10.18502/kls.v2i1.149 